Bangl. J. Vet. Med. (2008). 6 (1): 23-26

\title{
COMPARATIVE EFFICACY OF IMPORTED FOWL POX VIRUS VACCINE WITH LOCALLY PRODUCED ONE IN BACKYARD CHICKS
}

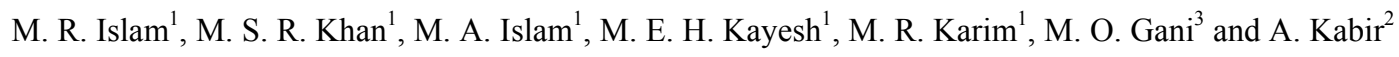 \\ ${ }^{1}$ Department of Microbiology and Hygiene, ${ }^{2}$ Department of Medicine, Faculty of Veterinary Science, \\ Bangladesh Agricultural University, Mymensingh-2202, Bangladesh, ${ }^{3}$ Goat and Sheep Production Research
}

Division, BLRI, Savar, Dhaka, Bangladesh

\begin{abstract}
A total of 80 experimentally reared backyard chicks with the history of non-vaccinated parents to FPV vaccine were used for the determination of persistence of maternally derived antibody in chicks and to compare the efficacy of Poxine ${ }^{\circledR}$ and DLS-FPV vaccine in protecting the chicks. Chicks were divided into five groups namely group A, B, C, D and E where each group contained 15 chicks except group A contained 20 chicks which was also used to determine the persistence of maternally derived antibody (MDA). Birds of group B and C were vaccinated with DLS-FPV at day 22 and 18 respectively through wing web puncture (WWP), whereas group D and E were vaccinated with Poxine ${ }^{\circledR}$ at day 36 and 18 respectively. Sera were randomly colleted from 10 chicks of each group at 7, 14 and 21 days of post vaccination for the determination of antibody titre using PHA test. Ten chickens from each group were challenged three weeks post vaccination with $10^{6}$ $\mathrm{EID}_{50} / 0.1 \mathrm{ml}$. "Take reaction" was recorded to assess the better immune response in different groups after vaccination. Birds of group B, C, D and E showed 100, 86.67, 93 and 86.67\% "take reaction", respectively. The highest Mean PHA titre was found $217.60 \pm 19.55$ in the chicks of group B. After challenge, the birds of group B and D showed 100\% protection, whereas birds of group $\mathrm{C}$ and $\mathrm{E}$ showed $93.33 \%$ protection and control group showed no protection. From the results of PHA test it may be concluded that both Poxine ${ }^{\circledR}$ and DLS-FPV vaccines are equally suitable and the chicks of nonvaccinated origin might be vaccinated with DLS-FPV at day 18 or 22 and 36 in case of Poxine ${ }^{\circledR}$ fowl pox virus vaccine.
\end{abstract}

Key words: Efficacy, fowl pox virus vaccine, backyard chicks, age

\section{INTRODUCTION}

Rural poultry occupies about $75-80 \%$ of the total poultry population in Bangladesh (Amin and Siddiky, 2003). Fowl pox (FP) is one of the most important problems in the development of poultry industry in Bangladesh. FP is still a malady of chicken of all ages, sexes and breeds either in organized farms or in backyard poultry farming system (Khondokar et al., 1994; Siddique et al., 1997; Siddiky et al., 2004). The disease is appearing as endemic every year in Bangladesh (FAO, 1995). This disease is characterized by pronounced inflammatory process, hyperplasia of epidermis and feather follicle with intracytoplasmic inclusions. It gradually terminates with the formation of scabs and desquamation of degenerated epithelium (Calnek, et al., 1997). Proper vaccination at proper age with dependable vaccine is the most effective means of controlling fowl pox. In Bangladesh, fowl pox vaccine manufactured by the Government is not adequate and that's why various private companies are engaged in importing vaccines. At present, FPV vaccines are being imported by Novartis Bangladesh Limited (Poxine $^{\circledR}$, Fort Dodge Laboratories, Iowa, USA), Advance Animal Science Co. Ltd. (Diftosec C.T. ${ }^{\circledR}$ ), Intervet (Nobilis ovodiphtherin ${ }^{\circledR}$ and Nobilis ${ }^{\circledR}$ A.E+Pox) and ACI Limited (CEVAC ${ }^{\circledR}$ MASS L) to meet up the crisis of FPV vaccine. Therefore, the present study was undertaken to compare the efficacy of Poxine ${ }^{\circledR}$ vaccine with Department of Livestock Services-Fowl pox virus vaccine (DLS-FPV vaccine) to recommend alternative FPV vaccine to user's level and also to suggest the proper time of vaccination.

\section{MATERIALS AND METHODS}

The study was conducted in the Department of Microbiology and Hygiene, Faculty of Veterinary Science, BAU, Mymensingh during the period from September 2006 to May 2007. The virulent FPV was revived from the laboratory repository following 12 passages in embryonated chicken eggs. 
The virus was propagated in 12 days old chicken embryo through chorio-allantoic membrane (CAM) route and this isolated virus was used in PHA test and challenge test. Lyophilized FPV vaccine produced at Livestock Research Institute (LRI), Mohakhali, Dhaka, Bangladesh and Poxine ${ }^{\circledR}$, a fowl pox virus vaccine imported by Novartis Bangladesh Limited were used for vaccination. Fertile eggs of chicken were purchased from the villages Sutiakhali, Vanghnamari Char and BAU Poultry Farm, Mymensingh and were used for hatching, isolation of FPV and determination of embryo infective dose fifty $\left(\mathrm{EID}_{50}\right)$ of FPV.

All the chicks were reared in a well-ventilated poultry shed of the Department of Microbiology and Hygiene, BAU, Mymensingh, providing feed and water ad libitum. For the determination of persistence of maternally derived antibody (MDA) titre, 20 chicks were used in group A and at the same time as unvaccinated control. Blood samples were collected at day 1, 4, 7, 10, 13, 16, 19, 22, 25, 28, 31 and 34 of age of chicks for sera and antibody titre was determined by PHA test as per method described by Zyambo et al. (1973) with some modifications of the method described by Tripathy et al. (1970). Remaining 60 chicks were divided into four groups namely B, C, D and E contained 15 chicks. Chicks of group B and C were vaccinated with DLS-FPV vaccine through wing web puncture (WWP) for once with the help of a bifurcated needle following usual and suggested schedule of vaccination at 22 and 18 days of age respectively. Similarly, chicks of group D and E were vaccinated with Poxine ${ }^{\circledR}$ FPV vaccine following usual and suggested schedule of vaccination at 36 and 18 days of age respectively. Blood was collected for sera on day 7, 14 and 21 of post vaccinations from randomly selected 10 birds of each vaccinated group and antibody titres were determined by PHA test to assess the efficacy of two vaccines. EID $_{50}$ of the isolated FP virus was determined according to the method described by Reed and Muench (1938). Ten birds from all vaccinated groups including unvaccinated control group were challenged with $10^{6} \mathrm{EID}_{50} / 0.1 \mathrm{ml}$ virulent FPV through wing web puncture (WWP) as described by Winterfield and Reed (1985). After challenge exposure all the chicks were kept in separate shed and observed up to 10 days for the development of clinical signs and symptoms.

\section{RESULTS AND DISCUSSION}

The results of persistence of MDA titre in chicks with the history of unvaccinated parents to FPV vaccine are presented in Table 1. It was observed that, highest mean MDA titre in chicks of Group A was $38.40 \pm 5.13$ found at the age of day 1 that declined to a negligible level $(\leq 4)$ at the age of day 13 . Moreover, the antibody titre started to decline after day 1 and persisted up to day 10 below the protective level.

Table 1. MDA titre in chicks of unvaccinated parent from day 1 to day 34

\begin{tabular}{|ll|}
\hline Age (day) & $\begin{array}{l}\text { Chicks with the history of } \\
\text { unvaccinated parent (Mean } \pm \text { SE) }\end{array}$ \\
\hline Day 1 & $38.40 \pm 5.13$ \\
Day 4 & $23.47 \pm 2.53$ \\
Day 7 & $13.33 \pm 1.01$ \\
Day 10 & $6.67 \pm .50$ \\
Day 13 & $\leq 4 \pm 0$ \\
Day 16 & $\leq 4 \pm 0$ \\
Day 19 & $\leq 4 \pm 0$ \\
Day 22 & $\leq 4 \pm 0$ \\
Day 25 & $\leq 4 \pm 0$ \\
Day 28 & $\leq 4 \pm 0$ \\
Day 31 & $\leq 4 \pm 0$ \\
Day 34 & $\leq 4 \pm 0$ \\
\hline
\end{tabular}

$\leq=$ Less than or equal to; FPV $=$ Fowl pox virus. 
Efficacy of fowl pox vaccine

No adverse reactions were observed in vaccinated birds following appearance of 'take' (Table 2). Birds of group B, C, D and E showed 100, 86.67, 93 and 86.67\% "take reaction", respectively which supports the findings of Fatunmbi and Reed (1996), Saini et al. (1990), Sarma and Sharma (1988) and Venkatasubba et al. (1978).

Table 2. 'Take reaction' of chicks of different groups after vaccination

\begin{tabular}{|llll|}
\hline Groups & \multicolumn{2}{l|}{ Reaction from vaccination } \\
\cline { 2 - 4 } & Age of vaccination (days) & Take & Percentage (\%) \\
\hline B & 22 & ${ }^{\mathrm{a}} 15 / 15$ & 100.00 \\
C & 18 & ${ }^{\mathrm{a}} 13 / 15$ & 86.67 \\
D & 36 & ${ }^{\mathrm{a}} 14 / 15$ & 93.00 \\
E & 18 & ${ }^{\mathrm{a}} 13 / 15$ & 86.67 \\
\hline
\end{tabular}

${ }^{\mathrm{a}}$ Nominator $=$ Number of chickens with take virus.

The highest Mean PHA titre was found $217.60 \pm 19.55$ in the chicks of group B vaccinated with DLS-FPV vaccine at day 22. The highest mean PHA titres of group D was $204.80 \pm 20.90$ found in the chicks vaccinated with Poxine ${ }^{\circledR}$ at day 36 which is equal to the mean PHA titre obtained from the group $\mathrm{C}$ vaccinated with DLSFPV (Table 3).

Table 3. Mean PHA titres of chicks of groups B and C vaccinated with DLS-FPV vaccine and groups D and E vaccinated with Poxine ${ }^{\circledR}$ FPV vaccine

\begin{tabular}{|c|c|c|c|c|c|c|}
\hline \multirow[t]{2}{*}{ Groups } & \multirow{2}{*}{$\begin{array}{l}\text { No. of } \\
\text { chicks for } \\
\text { sera } \\
\text { collection }\end{array}$} & \multirow{2}{*}{$\begin{array}{l}\text { Age at } \\
\text { vaccination } \\
\text { (days) }\end{array}$} & \multirow{2}{*}{$\begin{array}{l}\text { Prevaccination } \\
\text { titre } \\
(\text { Mean } \pm \mathrm{SE})\end{array}$} & \multicolumn{3}{|c|}{ Postvaccination PHA titres (Mean \pm SE) } \\
\hline & & & & 7 days & 14 days & 21days \\
\hline Group B & 10 & 22 & $\leq 4 \pm 0$ & $54.40 \pm 4.89$ & $134.40 \pm 22.27$ & $217.60 \pm 19.55$ \\
\hline Group C & 10 & 18 & $\leq 4 \pm 0$ & $51.20 \pm 5.23$ & $121.60 \pm 17.72$ & $204.80 \pm 20.90$ \\
\hline Group D & 10 & 36 & $\leq 4 \pm 0$ & $51.20 \pm 5.23$ & $128.00 \pm 23.37$ & $204.80 \pm 20.90$ \\
\hline Group E & 10 & 18 & $\leq 4 \pm 0$ & $49.60 \pm 6.06$ & $115.20 \pm 18.60$ & $198.40 \pm 24.23$ \\
\hline
\end{tabular}

$\mathrm{SE}=$ Standard error of Mean; $-=$ Not done; $\leq=$ Less than or equal to; PHA = Passive haemagglutination test.

After challenge, the birds of group B and D showed 100\% protection whereas, birds of group C and E showed $93.33 \%$ protection against virulent fowl pox virus and $0 \%$ protection was observed in control group. Though birds of group $\mathrm{C}$ and $\mathrm{E}$ carried high antibody titre following vaccination but one chick from each group got infection, it might be due to the lack of proper immunity development in that individual chick or due to other undefined factors. In maximum cases, the antibody titre recorded at different stages by PHA test was more than the findings of Sarma and Sharma (1988), Saini et al. (1990), Amin and Siddiky (2003). The variation in the PHA titre value might be due to use of different vaccine virus strain, vaccination method, age of vaccination and strain of challenge virus, which coincide the advocacy of Siddiky et al. (2004) and Siddique (1997) who reported that PHA test was highly sensitive in detecting specific antibodies following inoculation of birds with FPV. From the above findings it may be concluded that due to lower level of maternally derived antibody, fowl pox virus vaccination schedule in chicks reared with the history of parent unvaccinated to fowl pox virus vaccine might be at day 18 or 22 . It can also be concluded that Poxine ${ }^{\circledR}$ fowl pox virus vaccine could be used in chicks to control Fowl pox in Bangladesh as an alternate of DLS-FPV vaccine against fowl pox infection. 
Table 4. Mean PHA titre and protection percentage after challenge exposure with virulent FPV through WWP route in chicken vaccinated with DLS-FPV and Poxine ${ }^{\circledR}$ FPV vaccine

\begin{tabular}{|llllllll|}
\hline Group & $\begin{array}{l}\text { Age of } \\
\text { vaccina- } \\
\text { tion (day) }\end{array}$ & $\begin{array}{l}\text { Age of } \\
\text { challenge } \\
\text { (days) }\end{array}$ & $\begin{array}{l}\text { Mean PHA titre } \\
\pm \text { SE during } \\
\text { challenge }\end{array}$ & $\begin{array}{l}\text { No. of } \\
\text { chickens }\end{array}$ & $\begin{array}{l}\text { Challenge } \\
\text { route }\end{array}$ & $\begin{array}{l}\text { Chicken } \\
\text { infected }\end{array}$ & $\begin{array}{l}\text { Protec- } \\
\text { tion (\%) }\end{array}$ \\
\hline Group B & 22 & 43 & $217.60 \pm 19.55$ & 10 & wwp & $0 / 15$ & 100.00 \\
Group C & 18 & 39 & $204.80 \pm 20.90$ & 10 & wwp & $1 / 15$ & 93.33 \\
Group D & 36 & 57 & $204.80 \pm 20.90$ & 10 & wwp & $0 / 15$ & 100.00 \\
Group E & 18 & 39 & $198.40 \pm 24.23$ & 10 & wwp & $1 / 15$ & 93.33 \\
UVC & - & - & $\leq 4 \pm 0$ & 15 & wwp & $15 / 15$ & 00 \\
\hline
\end{tabular}

$\mathrm{SE}=$ Standard error of Mean; - = Not done; $\leq=$ Less than or equal to; PHA = Passive haemagglutination test; $\mathrm{UVC}=$ Unvaccinated control; WWP $=$ Wing Web Puncture.

\section{REFERENCES}

1. Amin MM and Siddiky MNA (2003). Efficacy of experimentally developed Fowl Cholera and Pigeon Pox vaccines. A Final Report of PLDP Research Project. pp. 1.

2. Calnek BW, Barnes HJ, Beard CW, McDougald LR and Saif YM (1997). Diseases of Poultry. $10^{\text {th }}$ edn., Iowa State University Press, Ames, Iowa, USA. pp. 675-683.

3. FAO (1995). Animal Health Year Book. Animal Production and Health Division, rA0-00100, Rome, Italy.

4. Fatunmbi OO and Reed WM (1996). Evaluation of a commercial modified live virus fowl pox vaccine for the control of "variant" fowl poxvirus infections. Avian Diseases 40 (3): 582-587.

5. Khondaker MSA, Khan MSR, Sarkar AJ, Rahman MM, Dass PM and Amin MM (1994). Physicochemical and Serological studies of a fowl pox virus vaccine. Bangladesh Journal of Microbiology 17 (2): 121-126.

6. Reed LJ and Muench H (1938). A simple method of estimating fifty percent end points. American Journal of Hygiene 27: 493-496.

7. Saini SS, Sodhi SS, Maiti KN and Sharma SN (1990). Combined oral vaccination against Newcastle disease and fowl pox. Indian Journal of Animal Sciences 60 (4): 387-389.

8. Sarma DK and Sharma SN (1988). Oral immunization of chicks with fowpox virus vaccines. Indian Journal of Animal Sciences 58: 743-747.

9. Siddiky MNA, Amin MM and Khan MSR (2004). Efficacy of experimentally developed pigeon pox vaccine against fowl pox. Bangladesh Veterinary Journal 21(2): 92-96.

10. Siddique B, Rahman MB, Amin MM and Rahman MM (1997). Antibody titres in chicks following pigeon pox virus inoculation. Bangladesh Veterinary Journal 14 (1-2): 12-14.

11. Tripathy DN, Hanson LE and Myers WL (1970). Passive haemagglutination test with fowl pox virus. Avian Diseases 14: $29-38$

12. Venkatasubba RC, Jayaraman MS, Masillamony PR, Thilakarajan N and Nachimuthu K (1978). Laboratory and field trials with cell culture fowl pox vaccine. Indian Veterinary Journal 55: 133-136.

13. Winterfield RW and Reed W (1985). Avian pox: infection and immunity with quail, psittacine, fowl and pigeon pox viruses. Poultry Science 64 (1): 65-70.

14. Zyambo GCN, Dennet DP and Johnson RH (1973). A passive haemagglutination test for the demonstration of antibody of infectious bovine rhinotrachitis / infectious pustular vulvovagainitis virus. I. Standardization of test components. Australian Veterinary Journal 49: 409-412. 